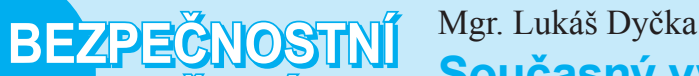 PROSTRED] Současný vývoj konfliktu v Podněstři na pozadí ukrajinské krize
}

Vojenské rozhledy, 2015, roč. 24 (56), č. 1, s. 38-45, ISSN 1210-3292 (tištěná verze), ISSN 2336-2995 (on-line). Článek prošel recenzním řízením.

\section{Recent development of Transnistrian conflict in the light of crisis on Ukraine}

\section{Abstrakt:}

Tento článek pojednává o mediálně málo reflektovaném zamrzlém konfliktu v Podněstří, který stoji ve stínu aktuální situace na Ukrajině. Nicméně v současné dobè situace v tomto de-facto státu na levém břehu Dněstru nabyla důležitosti $v$ souvislosti s aktivní politikou podpory Kremlu separatistickým snahám $v$ postsovětském prostoru. Zhodnoceni významu některých vnějšich aktérů, kteři se dlouhodobě v Podněstři angažují - tedy Ruska, Ukrajiny a Rumunska, či role organizovaného zločinu jako faktoru typického pro územi bez mezinárodního uznání, může nejen osvětlit neprehlednou situaci v Podněstři, ale také zasadit ostatni regionálni konflikty do patřičného kontextu.

\section{Abstract:}

This article analyses frozen Conflict in separatist region of Transnistria in the light of recent crisis on Ukraine. Despite standing in the shade of Ukraine, the importance of Transnistria has been once again highlighted by Russian support to separatist movements in post-soviet area. Hence text also argues, that by precise analysis of important agents involved in Transnistrian conflict, such as Russia, Ukraine or Romania, we can better understand not only current development in this ,,de-facto state“, but also put annexation of Crimea (or war in eastern Ukraine) into context. On the other hand, influence of Russian military presence in Transnistria on Ukraine war effort is also important and deserves to be closely studied.

\section{Klíčová slova:}

Podněstří, ukrajinská krize, separatismus, zamrzlý konflikt, Moldávie, válka na Ukrajině, ruská politika

\section{Key words:}

Transnistria, Separatism, War in Ukraine, Russian politics, Moldova, Frozen conflict, Ukraine Crisis 


\section{Úvod}

Mocenský vzestup Ruska, separatismus v postsovětských republikách a také energetická bezpečnost - to jsou tři z významných témat, která v poslední době dominují bezpečnostní agendě evropských členů NATO. Hledáme-li oblast, kde všechny tři tyto problémy splynuly v jeden celek, nabízí se logicky Ukrajina s aktuálními konflikty v Doněcké a Luhanské oblasti či anektovaný Krymský poloostrov. Dříve či později však narazíme také na tzv. zamrzlý konflikt v Podněstř́í, který s tím na Ukrajině sdílí mnoho společných rysů. Navíc celou řadou analytiků byla vojenská angažovanost Kremlu na Ukrajině nezřídka vysvětlována právě snahou zajistit pozemní koridor do Podněstř́i [1][2] a vyhovět tak snaze režimu v hlavním městě Podněstří Tiraspolu o připojení k Rusku [3].

Dlouhodobě existující napětí mezi Moldávií a secesionistickým Podněstřím lze po právu charakterizovat jako jeden ze zamrzlých konfliktů v postsovětském prostoru. Po krátké a intenzivní „,horké fázi“ na počátku devadesátých let, která si vyžádala přes tisíc obětí na životech, došlo k zafixování pozic obou stran a od té doby je situace fakticky neměnná. Konfliktu nechybí téměř nic z komplexity a složitosti mediálně více reflektované východní Ukrajiny či Jižní Osetie - má však také svá specifika, mezi něž lze jednoznačně zařadit téměř absolutní nezájem mezinárodního společenství. Současné mírné zvýšení pozornosti sdělovacích prostředků o tuto oblast lze přičíst tradičnímu souboji proruské a proevropské poloviny Moldavského politického spektra v listopadových parlamentních volbách spíše než situaci v samotném Podněstří.

Zatímco je tedy konflikt mediálně téměř ignorován, z hlediska evropské bezpečnosti podobnou chybu udělat nelze. Minimálně od vstupu sousedního Rumunska do NATO a EU už Podněstř́ není „daleko“ - ani geopoliticky, ani ekonomicky. Stabilita, resp. nestabilita regionu tak dnes přímo ovlivňuje situaci v členských státech Aliance a EU. Nakonec také rumunská politika ,jednoho národa a dvou států“ směrem k Moldávii efektivně vytyčila hranice Evropy na Dněstru, s čímž ovšem v konečném důsledku není spokojen nikdo.

V současné době však Podněstří nabylo na významu především v souvislosti s krizí na Ukrajině. Zhodnocení některých vnějších aktérů, kteří se dlouhodobě v Podněstří angažují - tedy Ruska, Ukrajiny a Rumunska, či zhodnocení faktorů, jakým je chronický organizovaný zločin v Podněstří - může nejen usnadnit nepřehlednou a málo známou situaci na levém břehu Dněstru, ale také zasadit ostatní regionální konflikty do patřičného kontextu.

\section{Role Kremlu - regionální konotace}

Naprosto fundamentálním faktorem působícím na dynamiku konfliktu v Podněstří a na Moldávii samotnou byl vždy vliv Ruska. Moldávie sice nemá podobně rozsáhlé prozápadní ambice jako sousední Ukrajina, tyto tendence však především u pravicového spektra moldavské politiky nechybějí a nejnověji se projevily opět po parlamentních volbách na konci listopadu 2014, kde i přes vítězství proruské Socialistické strany získala většinu křesel proevropsky orientovaná pravice [4]. V minulosti Kreml neváhal situaci ve vztahu ke Kišiněvu vyostřit, a to ve chvíli, kdy byl proevropským tendencím 
v Moldávii dán volný průchod. A nezřídka rovněž za použití podněsterské karty. Ruský protest proti průběhu nedávných parlamentních voleb, zahrnující také kritiku znemožnění hlasování obyvatelům Podněstří, je tedy nejspíše jen prvním krokem - ovšem krokem typickým [5]. Z ostřejších kroků, které Kreml v minulosti použil, lze namátkou zmínit třeba zastavení dodávek energií a paliv či ruské odmítnutí splnit již dohodnuté stažení vojáků z území Podněstří v letech 2001 a 2003. Současné zablokování rozhovorů o řešení konfliktu ve formátu tzv. 5+2 (Moldávie, Podněstří - a mediátoři z USA, EU, OBSE, Ruska a Ukrajiny), který se naposledy sešel v červnu 2014, lze do jisté míry přičítat ruské nevoli vůči podepsání asociační dohody mezi Kišiněvem a Bruselem [6]. Je př́iznačné, že víceméně ta stejná otázka v sousední Ukrajině stála za protesty na Majdanu a v důsledku tak také stála na počátku současného ruského angažmá na východní Ukrajině. Obavy o opakování ukrajinského scénáře v Podněstří tak díky těmto paralelám neznějí nijak nerealisticky.

Konfliktní potenciál Podněstř́i ale není úzce vázán pouze na vztahy Kišiněv-Moskva. Sousedství Podněstří s Ukrajinou poskytuje Rusku nové př́ležitosti eskalovat tamější situaci s cílem odstrašit Kyjev. Samotná Moldávie (a tím spíše Podněstří) sice postrádá důležitost Ukrajiny - až do roku 2014 však nabízela snazší cestu k ukázce ruského vlivu na separatistické regiony. Podněsterský konflikt tak svým způsobem sloužil Rusku jako „pokusný králík“، Celá řada přístupů použitých v současné době na Ukrajině včetně mechanismů vojenské podpory separatistických vůdců Doněcku a Luhansku byla v praxi ověřována již dříve v Tiraspolu. Koneckonců sestřel malajského dopravního letadla z července 2014, provedený pravděpodobně ruskou osádkou protiletadlového kompletu BUK-M/SA-11 nese výraznou podobnost se sestřely moldavských letadel ruskou PVO v Podněstří už v létě roku 1992.

Mediální neatraktivnost Podněstř́i však dávala Rusku dlouhodobě možnost demonstrovat zde své zájmy bez toho, aby mezinárodní společenství významněji protestovalo - a přitom zaručit, že zpráva, kterou tím Kreml vyšle, bude doručena adresátu (v současné době Ukrajině). V této souvislosti se opět nabízí nejen energetická krize mezi Podněstrrím a Moldávií, která časově a ideově předcházela podobnému sporu mezi Ruskem a Ukrajinou (na přelomu let 2008/2009 a nověji v září/ř́ijnu roku 2014), ale především pohled na Krym.

\section{Podněstří jako hrozba, nebo bezpečnostní dilema? - Vztah s Ukrajinou}

Zatímco analyzovat Ruský postoj vůči Podněstří je relativně jednoduché, zhodnotit vztah tohoto separatistického regionu se sousední Ukrajinou je skutečný oříšek. Zatímco ještě okolo roku 2000 vnímal Tiraspol Ukrajinu jako přirozenou náhradu tehdy klesajícího ruského vlivu, v roce 2005 došlo k radikálnímu obratu. Př́íčiny je třeba hledat v širším kontextu ukrajinské politiky po tzv. „oranžové revoluci“v prosinci 2004 [7]. Po proruském intermezzu za prezidenta Janukovyče se dnešní politické elity k podezřívavému přístupu k Podněstří vrátily. Staronový ukrajinský postoj ovšem není ani tak namířen proti Podněstří samotnému, jako spíš vůči ruské vojenské přítomnosti na jeho území [8] - vzhledem k nereálným ambicím země vstoupit do NATO jsou totiž ruské jednotky na jejích západních hranicích problematickým momentem. 
Od anexe Krymu navíc dominuje pohledu politických elit v Kyjevě okolo prezidenta Porošenka vnímání Podněstř́ jako skutečné hrozby teritoriální integritě Ukrajiny. Území je chápáno jako ruská loutka a nástupní prostor další ruské agrese, či dokonce v extrémním př́padě jako příčina ruské anexe Krymu. Koneckonců termín Novorusko („Novorossiya”), který povstalci na východě Ukrajiny i ruský prezident Putin opakovaně použili k pojmenování svých oblastí, označoval v carském Rusku gubernii táhnoucí se od Azovského moře až právě do Podněstří.

Po násilných krvavých střetech mezi proruskými a proukrajinskými demonstranty v Oděse na začátku května 2014 obavy Kyjeva z možnosti rozšíření konfliktu k Podněstří vygradovaly do skutečných vojenských příprav. Přibližně od července 2014 začala Ukrajina s posilováním vojenské prrítomnosti v regionu a rovněž s opevňováním $450 \mathrm{~km}$ dlouhé hranice s Podněstřím [9]. Tato oblast je navíc obývána především ruskojazyčným obyvatelstvem (včetně etnických Bulharů nebo Gagauzů), kteří masivně podporovali Stranu regionů bývalého proruského prezidenta Ukrajiny Viktora Janukovyče, což stabilitě v tomto regionu nepřidává.

V kontrastu proti Ukrajinským opatřením ale stojí poměrně slabá vojenská přítomnost Ruska v Podněstř́i, která oficiálně dosahuje počtu pouze cca 1500 mužů tzv. Operační skupiny ruských vojsk (Operational Group of Russian Forces (Operativnaya Gruppa Rossiyskih Voysk - OGRV) a 400 mužů z peacekeepingové mise ustavené v roce 1992. Nakolik je toto číslo pouze fiktivní, je obtížné odvodit, nicméně určité vodítko může poskytnout struktura ruských sil, která ukazuje na uskupení o velikosti až samostatné brigády. Podobná ruská brigáda umístěná např́klad v Abcházii obsahuje také ženijní prapor, zesílené dělostřelectvo, průzkumný prapor a další útvary bojové podpory a bojového zabezpečení, což významně zvyšuje konečné početní stavy. Navíc zjištěné počty specialistů (leteckého personálu, spojařů, dělostřelců atd.) účastnících se různých cvičení v posledních letech naznačují, že by ruské síly mohly dosáhnout, či už skutečně dosáhly brigádní úrovně (tedy 6500 mužů) [10]. Dohromady s místními vojenskými a bezpečnostními složkami, které jsou nepřímo také placeny Ruskem, se lze dostat až k číslu 12000 ozbrojenců. Zvláštní obavy na ukrajinské straně vyvolává také několik stovek kozáků, kteří mohou být údajně podněsterskou tajnou službou použity k infiltraci v okolí Oděsy [11]. Přestože veřejné mínění údajně právě jejich zapojení viní z rozpoutání šarvátek v Oděse 2. května 2014, prozatím neexistují žádné přímé důkazy, že by tomu tak skutečně bylo [12].

Na Podněsterské straně jsou vojenská opatření Ukrajiny na společné hranici vnímána rovněž s velkým znepokojením. Jeden z bývalých úředníků podněsterského ministerstva zahraničí situaci ve vztahu k Ukrajině výstižně komentoval slovy „Když se vám země rozpadá pod rukama, pak je všechno vnímáno jako hrozba“ [13]. Panuje zde rovněž obava, že představitelé Ukrajiny mohou reagovat pod tlakem bojů na východě země v současné situaci spíše iracionálně a situaci ve vztahu k Podněstř́i vyhrotit, což koneckonců odpovídá dlouhodobému obrazu Podněstř́i v ukrajinských médiích. Celá situace tak dostává podobu klasického bezpečnostního dilematu.

Podněsterská strana v současné době reaguje na obavy z Ukrajiny celou řadou demonstrací síly, které v minulosti měly vždy spíše ,,antimoldavský“ nádech. V době vrcholících bojů na východě Ukrajiny byly 7. srpna 2014 podněsterské bezpečnostní síly uvedeny do stavu pohotovosti a 21. srpna se objevily zprávy o všeobecné mobilizaci [14]. 
Byt’ byly později tyto zprávy dementovány a jednalo se pouze o povolání záložníků k cvičení spolu s ruskými vojsky v zemi, ukazují na atmosféru napětí v oblasti.

Vystupňování hysterie na obou stranách hranice má také prokazatelný dopad na obyvatelstvo Podněstř́i. V reakci na vykreslování Ukrajiny jako nestabilní země ovládané fašisty, poklesl mimo jiné přeshraniční styk s Oděskou oblastí na minimum. To přirozeně zasahuje jak turismus, tak také rodinné vazby celé řady občanů na obou stranách hranice. Např́ílad i představitelé separatistické republiky začali raději k cestování do zahraničí namísto obvyklého letiště v Oděse využívat Kišiněv.

Největší dopady lze ovšem očekávat v ekonomice. Podle odhadů ze začátku roku 2014 měl klesnout HDP o 11 \% [15]. Po událostech na Ukrajině bude skutečné číslo mnohem horší. Velká část ekonomických aktivit má pololegální podobu a v každém príípadě potřebuje snadno dostupný př́stav v Oděse. Napětí na hranicích zasáhlo dokonce i etablované obchodní vztahy. Napríklad poměrně moderní ocelářský komplex v Ribnici, odvádějící druhou nejvyšší sumu na daních v zemi, závisí na surovinách z ukrajinských dolů, jejichž dodávky jsou v současné době značně nepredvídatelné. Př́mé ekonomické dopady napětí s Ukrajinou už lze intenzivně pocitovat nyní. At' už se jedná o $15 \%$ snížení a následné zmrazení platů ve veřejném sektoru do konce roku 2014 či o problémy s důchody vyplácenými z Ruska. Vláda v Tiraspolu přirozeně z obtižíi viní Kišiněv a Kyjev, nicméně nevhodná struktura ekonomiky (40 \% práceschopného obyvatelstva zaměstnáno ve veřejné sfére), rozsáhlá korupce, velké množství důchodců atd. patrně hrají mnohem větší roli.

I přes rostoucí pocit vzájemného ohrožení ale není prríliš reálné očekávat př́ímou agresi kterékoliv z obou stran. Ukrajina je jednoznačně vázána na východě a Podněstří si nemůže dovolit poštvat proti sobě svého jediného souseda, přses kterého mu proudí zboží, plyn a suroviny. To může také vysvětlit, proč Tiraspol neuznal separatistické lidové republiky v Luhansku a Doněcku.

\section{Besarabské jablko sváru - role Rumunska}

Poněkud pozapomenutým aktérem zamrzlého konfliktu v Podněstř́ je v současné době Rumunsko. Bukurešt' např́ílad nikdy nebyla - přes opakované snahy - přizvána k jednáním ve formátu $5+2$ o vyř̌šení situace $\mathrm{v}$ separatistické oblasti [16]. Nicméně právě přijetím Rumunska do EU v roce 2007 se Podněstř́ již nadále nenachází na odlehlé periferii a jeho relevance vzrostla.

Vztahy obou zemí jsou přitom zatíženy sovětskou minulostí a minimálně v počátcích vzniku Podněsterské Moldavské republiky hrály důležitou úlohu. Za svého historického předchůdce Podněstří považuje Moldavskou autonomní sovětskou socialistickou republiku, která byla $\mathrm{v}$ roce 1924 vytvořena z části ukrajinského území a obsahovala i levý břeh Dněstru a zcela zjevně sloužila k prezentaci sovětských územních nároků na celou Moldávii. Její většina (tzv. Besarábie) byla totiž v meziválečném období součástí Rumunska, což trvale zatěžovalo sovětsko-rumunské vztahy. V roce 1940 Sovětský svaz Besarábii obsadil a na jejím území vznikla Moldavská sovětská socialistická republika, k níž bylo připojeno území dnešního Podněstří. Ztráta Besarábie pak byla hlavní prř́činou rumunské účasti ve válce proti SSSR. Celá oblast dnešní Moldávie i s pravým břehem Dněstru se tak naposledy na tři roky dostala po rumunskou správu. 
Moldavská SSR byla obnovena v roce 1944 a zůstala pak součástí Sovětského svazu až do jeho rozpadu v roce 1991 .

I v rámci společné svazové republiky bylo Podněstří sovětským ústředím protežováno. Odtud pocházely politické elity a právě tady byl rozvíjen těžký průmysl. Ve chvíli rozpadu Sovětského svazu se tak předpoklady o větší důvěryhodnosti podněsterských elit plně potvrdily. Zatímco Lidová fronta $\mathrm{v}$ Moldávii organizovala rozsáhlé demonstrace ve prospěch sjednocení s Rumunskem, opoziční hnutí (OSTK - odbory), čerpající podporu především v průmyslových oblastech okolo Dněstru (tedy převážně ruskojazyčných), volala po zachování úzkých vazeb na moskevské centrum [17]. Etnický rozměr těchto rozporů byl tedy ve skutečnosti méně významný než aspekt kulturní a jazykový. Jak z jazykových, tak také z ekonomických důvodů například Podněstří podporovalo moskevský puč v roce 1991, zatímco Kišiněv jej odmítl.

Samotná otázka spojení s Rumunskem pak hrála svou roli v rumunské i Moldavské politice po celá devadesátá léta. Strach z něj dovedli podněsterští vưdcové dovedně využívat. V dnešní době je ekonomická realita Rumunska a Moldávie zcela odlišná a oficiální politická podpora spojení se vytratila, přestože i Bukurešt’ je v některých místech zaplavena nápisy „Basarabia Pământ Românesc“ („Moldávie je Rumunsko“). Blízký, víceméně emocionální vztah si Rumunsko k Moldávii udržuje nadále ve sloganech jako „bratři za řekou Prut", které lze zaslechnout i na oficiálních akcích. Ojediněle - i když velmi opatrně - pak dávají některé konkrétní osoby napojené na dlouholetého rumunského prezidenta Băsesca najevo revizionistické tendence, ale potenciál těchto témat nějakým způsobem polarizovat společnost obou zemí je již téměř nulový.

Přesto má samotné Podněstří pro Rumunsko stále klíčový význam. Právě přes Podněstři totiž vede klíčový plynovod a ropovod nejen do samotné Moldávie, ale také do Bulharska a Rumunska. Na levém břehu Dněstru tak již dávno došlo k propojení současných silových nástrojů ruské politiky - energetické bezpečnosti a podpory proruského separatismu. A právě Rumunsko se může nechtěně stát jejich první obětí z řad Evropské unie.

\section{Organizovaný zločin}

Bylo by iluzorní předpokládat, že situace v Podněstří je determinována výhradně externími aktéry. Jakkoliv je třeba vliv Ruska nesporný a absence mezinárodního uznání (alespoň v takové míře, jaké se dostalo Kosovu) ovlivňuje fakticky všechny oblasti fungování země, existují i nezanedbatelné vnitropolitické aspekty. V Evropě lze nalézt pouze dvě země, jejichž nejvyšší představitelé měli tak úzké vazby na skupiny organizovaného zločinu. Kromě Kosova se jedná právě o Podněstří.

Spojení se světem Tiraspol tradičně obstarával přes ukrajinský přístav Oděsa - vlivem rozšířené korupce je tento kanál využíván také k ilegálnímu transportu nejrůznějších komodit. Zatímco v kosovském př́padě se běžně jednalo o drogy či kradená auta, Podněstři disponuje jinou lukrativní komoditou - zbraněmi [18]. Ty jsou v zemi vyráběny minimálně od roku 1996, a to v továrnách ovládaných nejmocnějšími členy vládnoucích elit včetně bývalého prezidenta Igora Smirnova. Další vydatný zdroj představují obrovské sklady munice patřící ještě někdejší sovětské armádě. V době svého vrcholu v roce 2004 dosáhla hodnota pašovaných zbraní stěží představitelné hodnoty 20 miliard dolarů. Hlavní položku přirozeně představují ruční palné zbraně, munice a součástky 
pro nástražné výbušné systémy. Výjimkou nejsou však ani protiletadlové komplety nebo obrněná vozidla, která byla dodávána do Sýrie a Libanonu. Nejzávažnější (avšak nepotvrzené) jsou zprávy o pašování štěpného a radioaktivního materiálu vhodného k výrobě špinavé bomby [19]. Mezi hlavní zákazníky podle ne zcela věrohodných zpráv patří celá řada organizací typu Hizballáh nebo Hamás - ovšem i teroristé či povstalci v Kosovu a Čečensku [20], což do jisté míry popírá argumenty o Rusku stojícím v pozadí těchto aktivit (naopak je téměř jasné, že přes Podněstří realizuje Moskva dodávky vojenské techniky do některých kontroverzních států).

Nedostatek mezinárodního uznání a konec ukrajinské podpory v roce 2005 dohnal Podněstřri k obrovské závislosti na ilegálním obchodu. Paradoxně je tak možno říct, že ignorování Tiraspolu vede k bezprecedentnímu ohrožení evropské bezpečnosti je jistě velkým luxusem mít na hranicích EU zemi, která dodává zbraně teroristům. Navíc nedostatek koherence v evropské zahraniční politice činí Evropskou unii poměrně nevhodným formátem pro řešení tohoto problému. NATO, které disponuje americkými zdroji, ale také třeba tureckými zkušenostmi s podobnými konflikty na Kavkaze, pak zase neprojevuje o problematiku dostatečný zájem. Za takové situace je každé řešení závislé pouze na Rusku - jemuž ovšem dosavadní stav vyhovuje.

\section{Postsovětský skanzen?}

„Zamrzlost“ se v př́ípadě Podněstř́i nevztahuje pouze na samotný konflikt. Tímto slovem je možno charakterizovat celkovou ustrnulost tamějších poměrů. Při jeho návštěvě se lze stěží ubránit dojmu jakési cesty časem. Celá země se tak více než čemu jinému podobá kulise z „béčkového“ špionážního thrilleru, jejichž děj je občas do Podněstř́ skutečně zasazen. Tomu odpovídá vše; od státní symboliky vycházející ze sovětského vzoru až po personální propojenost současných a bývalých sovětských elit.

Nicméně dokud bude Podněstř́i v ruské zahraniční politice chápáno jen v kontextu konfliktu na Ukrajině či jako „eso v rukávu“ ve směru k Moldávii, zůstane jeho role omezena pouze na nástroj politického tlaku. Rozšíření konfliktu dále do oblasti Černého moře by totiž i pro Rusko představovalo vojensky a politicky mnohem nákladnější podnik než operace v Donbasu. Koneckonců osamocená - byt' krvavá - proruská demonstrace v blízké Oděse 2. května 2014 jasně ukázala na limity lidové podpory ruské agresi v tomto regionu. Naopak těsné vítězství proevropských stran v parlamentních volbách v Moldávii na konci listopadu 2014 patrně povede Moskvu k využití Podněstří k destabilizaci a nátlaku na Kišiněv, což ovšem paradoxně může uklidnit situaci podél ukrajinských hranic. V této souvislosti by ale byla chyba, kdyby Podněstří opět zmizelo ze zorného pole mezinárodního společenství. Jeho blízkost EU a NATO z něj totiž potenciálně dělají větší zdroj nestability než relativně vzdálený Donbas či Krym.

Po více než dvaceti letech své existence nicméně Podněsterská moldavská republika stále zůstává „de facto státem“, tedy mezinárodně neuznanou entitou, v níž své zastupitelské úřady otevřela jen Abcházie, Jižní Osetie a Náhorní Karabach - a to ke zvýšení prestiže zjevně nestačí. Její samotná existence povyšuje pojem ,zamrzlý konflikt" z pouhého popisu daného stavu na svébytnou ideologii a v kontextu konfliktu na Ukrajině slouží jako precedens především pro separatistické oblasti okolo Doněcka a Luhanska. Jestliže však u některého z klíčových politiků na ukrajinské či ruské straně nedojde 
ke „zkratu“ po vzoru gruzínského prezidenta Michaila Saakašviliho v roce 2008, zůstane udržení „statu quo“ samotnou podstatou „byti““ této separatistické republiky.

\section{Použitá literatura:}

[1] Kosienkowski, M. Ukraine and Transnistria: A TroubledBorderland. In New Eastern Europe. http://www. neweasterneurope.eu/articles-and-commentary/1342-ukraine-and-transnistria-a-troubled-borderland [ke dni 19.12.2014].

[2] Groll, E. What Would Russian Troops Do Once They Cross the Ukrainian Border?. In Foreing Policy. http:// foreignpolicy.com/2014/04/14/what-would-russian-troops-do-once-they-cross-the-ukrainian-border/ [ke dni 19.12.2014].

[3] Pridnestrovie in Context of Ukraine. In Ari Rusila's Balkan blog. https://arirusila.wordpress.com/ 2014/03/29/transdniestria-in-context-of-ukraine/ [ke dni 19.12.2014].

[4] Moldovans choose Europe, barely. In The Economist, http://www.economist.com/news/europe/21635339moldovans-choose-europe-barely [ke dni 19.12.2014].

[5] Russia issues thinly-veiled threat to Moldova not to forge close rties with EU after key elections produce narrow victory for pro-Western parties. In The Daily Mail. http://www.dailymail.co.uk/news/ article-2856029/Will-Putin-accept-result-Pro-Europe-coalition-narrowly-wins-key-Moldovan-electionholds-surging-Russian-leaning-parties.html

[6] Całus, K. Chisinau is taking a tougher stance on Transnistria. http://www.osw.waw.pl/en/publikacje/ analyses/2014-11-05/chisinau-taking-a-tougher-stance-transnistria [ke dni 19.12.2014].

[7] Urse, C. Solving Transnistria: Any Optimists Left? In PfP Consortium Quarterly Journal Spring 2008. http://www.isn.ethz.ch/Digital-Library/Publications/Detail/?ots591=cab359a3-9328-19cc-a1d28023e646b22c\&lng=en\&id=57339 [ke dni 19.12.2014].

[8] Całus, K. Chisinau is taking a tougher stance on Transnistria. http://www.osw.waw.pl/en/publikacje/ analyses/2014-11-05/chisinau-taking-a-tougher-stance-transnistria [ke dni 19.12.2014].

[9] Kosienkowski, M. Ukraine and Transnistria: A Troubled Borderland. In New EasternEurope. http://www. neweasterneurope.eu/articles-and-commentary/1342-ukraine-and-transnistria-a-troubled-borderland [ke dni 19.12.2014].

[10] Minzarari, D. Ukraine Taking Drastic Measures to Diminish the Risk of an 'Odessa People's Republic'. In Eurasia Daily Monitor Volume. http://www.jamestown.org/single/?tx_ttnews\%5btt_news $\% 5 \mathrm{~d}=42752$ \&tx_ttnews\%5bbackPid\%5d=228\&cHash=1580aed0b26c1482691c346c4c01d54a\#.VIWcm00tDIW [ke dni 19.12.2014].

[11] Minzarari, D. Ukraine Taking Drastic Measures to Diminish the Risk of an 'Odessa People's Republic'. In Eurasia Daily Monitor Volume. http://www.jamestown.org/single/?tx ttnews\%5btt news $\% 5 \mathrm{~d}=42752$ \&tx_ttnews\%5bbackPid\%5d=228\&cHash=1580aed0b26c1482691c346c4c01d54a\#.VIWcm00tDIW [ke dni 19.12.2014].

[12] Sobják, A. Will Transnistria Be Cast in the „Novorossiya” Project? In PISM. http://www.pism.pl/files/ ?id_plik=18298 [ke dni 19.12.2014].

[13] KOSIENKOWSKI, M. Ukraine and Transnistria: A TroubledBorderland. In New EasternEurope. http://www.neweasterneurope.eu/articles-and-commentary/1342-ukraine-and-transnistria-a-troubledborderland [ke dni 19.12.2014].

[14] Transnistria mobilizes its army: Russian official visits region. In Moldova.org, http://www.moldova.org/ transnistria-mobilizes-its-army-russian-official-visits-region/ [ke dni 19.12.2014].

[15] Benea, R. Alegerile moldoveneşi Transnistria. http://www.europalibera.org/content/transcript/26717872.html [ke dni 19.12.2014].

[16] Benea, R. Conflictultransnistrean - ce rol ar puteajucaRomânia? http://www.europalibera.org/content/ article/2196426.html [ke dni 19.12.2014].

[17] Johansson, A. The Transnistrian Conflict after the 2005 Moldovan Parliamentary Elections, In Journal of Communist Studies and Transition Politics, Vol. 22, Issue 4, 2006. http://www.tandfonline.com/doi/ full/10.1080/13523270601019565\#tabModule [ke dni 19.12.2014].

[18] VDovî, L., Opriș, M. and Mogoș, A. Transnistria - Europe's hub of smuggling and trafficking. http://www.investigatii.md/eng/index.php?art=221 [ke dni 19.12.2014].

[19] Transdniestr: Missing Missiles Raising Fears of ,Dirty Bombs“ For Sale“, http://www.globalsecurity.org/ security/library/news/2003/12/sec-031210-rferl-171503.htm [ke dni 19.12.2014].

[20] Modlova.org: Italian daily: terrorists are armed in Transnistria, http://www.moldova.org/italian-dailyterrorists-are-armed-in-transnistria-39287-eng/ [ke dni 6.1.2015]. 